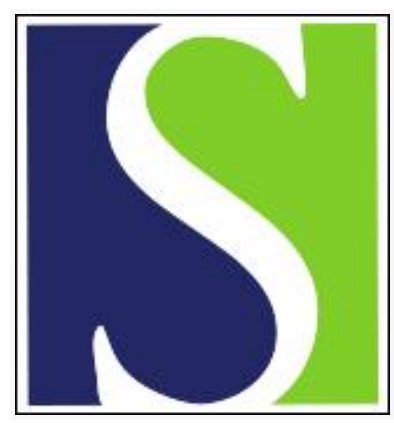

Scand J Work Environ Health 2002;28(2):94-108

https://doi.org/10.5271/sjweh.653

Issue date: Apr 2002

Effects of stable and changing demand-control histories on worker health

by de Lange AH, Taris TW, Kompier MAJ, Houtman ILD, Bongers PM

Affiliation: Department of Work and Organizational Psychology, Nijmegen University, PO Box 9104, NL-6500 HE Nijmegen, Netherlands. A.delange@psych.kun.nl

Refers to the following text of the Journal: 1999;25(6):550-557

The following articles refer to this text: 2003;29(1):1-4;

2007;33(4):252-259; SJWEH Supplements 2008;(6):22-32;

2017;43(1):50-58; 2020;46(3):311-320; 2023;49(2):95-98

Key terms: demand-control history; demand-control model; exposure; health; job change; longitudinal research; strain hypothesis; worker health

This article in PubMed: www.ncbi.nlm.nih.gov/pubmed/12019593 


\title{
Effects of stable and changing demand-control histories on worker health
}

\author{
by Annet $H$ de Lange, MA, ${ }^{1}$ Toon W Taris, PhD, ${ }^{1}$ Michiel AJ Kompier, PhD, ${ }^{1}$ Irene LD Houtman, PhD, ${ }^{2}$ \\ Paulien M Bongers, $P h D^{2,3}$
}

\begin{abstract}
de Lange AH, Taris TW, Kompier MAJ, Houtman ILD, Bongers PM. Effects of stable and changing demandcontrol histories on worker health. Scand J Work Environ Health 2002;28(2):94-108.
\end{abstract}

\begin{abstract}
Objectives The present study examined effects of stability and change in exposure to job demands and job control (demand-control histories) in relation to the strain hypothesis of Karasek's demand-control model.

Methods The hypotheses [(i) high (low) levels of ill health were expected for workers exposed to stable 1 levels of high (low) job demands and low (high) job control; (ii) decreases (increases) in strain-related health outcomes were expected for workers with positive (negative) changes in job demands and job control; (iii) workers reporting major changes in job demands or control were expected to report more "objective" job changes] were tested with a group-by-time analysis of variance using data from a four-phase Dutch cohort study on musculoskeletal disorders, absenteeism, stress, and health. Associations between demand-control histories and job changes were tested in a log-linear analysis.

Results The hypotheses for the stable exposure groups were supported for depression and job satisfaction. Those for positive and negative changes were partially supported. There was no relation, however, between the level of stability or changes in exposure to demands and control for the registered duration and frequency of sickness absence. Finally, the results showed that workers reporting major changes in demand-control histories over time had more job changes, and those reporting job changes towards high strain jobs evaluated the changes as more distressful.
\end{abstract}

Conclusions This longitudinal study supports the strain hypothesis of the demand-control model and shows a significant association between major changes in demand-control histories and job changes.

Key terms demand-control model, exposure, health, job change, longitudinal research, strain hypothesis.

In 1979 Robert Karasek introduced his job demand-control model (1). Due to its simplicity and broad applicability, this model has become very influential in occupational health psychology and epidemiology $(2,3)$. According to it, psychosocial work environments can be characterized in terms of a combination of job demands and job control (or decision latitude). Job demands refer to the psychological stressors in the work environment, such as having to complete much work and working under time pressure. Job control consists of two components, namely, decision authority (opportunity to make decisions concerning the job) and skill discretion (amount of skill used in the job), which are usually combined into a single measure.

Based on various combinations of demands and control, the demand-control model distinguishes among four types of jobs, namely, high-strain jobs, low-strain jobs, active jobs, and passive jobs. High-strain jobs are characterized by high demands and low control. People working in such jobs are expected to have a relatively high risk of developing high blood pressure and ill health $(1,3,4)$. In contrast, people working in low-strain jobs, which are characterized by low demands and high control, develop a lower-than-average number of health complaints across time. Active jobs are characterized by high job demands and high job control. These jobs are expected to result in an average number of health complaints (4). The same number of health complaints is expected for passive jobs, which are characterized by low demands and low control.

The assumption that high-strain jobs result in health complaints is known as the strain hypothesis of the

1 Nijmegen University, Nijmegen, The Netherlands.

2 TNO Work and Employment, Hoofddorp, The Netherlands.

3 Body@work, Research Center On Physical Activity, Work And Health TNO-VU, Nijmegen, The Netherlands.

Reprint requests to: Dr AH de Lange, Department of Work and Organizational Psychology, Nijmegen University, PO Box 9104, NL-6500 HE Nijmegen, The Netherlands. [Email: A.delange@ psych.kun.nl] 
demand-control model. It is supported by an impressive body of mainly cross-sectional research (5-7). However, covariation is not causation, and therefore it is fortunate that, over the last decade, several longitudinal studies examining the demand-control model have been published as well, albeit less consistently and, perhaps, less convincingly than earlier cross-sectional studies (8). One explanation may be that most longitudinal studies on the demand-control model are based on a single point assessment of workers' perceptions of their work situation at the time they filled out the questionnaire (9-11). In other words, workers' judgments of their work situation may be affected by external factors and possibly result in less accurate and less reliable assessments of the characteristics of their work. Longitudinal measurement of these characteristics may circumvent this problem by providing a more stable and, therefore, more reliable repeated-measures assessment of a worker's work environment. This circumvention, in turn, may lead to more consistent evidence for the causal effects of the work environment on worker health.

A related issue is the effect of cumulative exposure to high strain on worker health. Karasek \& Theorell (4) have argued that duration of exposure to an unfavorable work situation is related nonlinearly to health, such that long-term exposure has comparatively stronger detrimental effects than short-term exposure (12). Unfortunately, insofar as their research designs have allowed researchers to examine the development of ill health in response to chronic job strain, they have tended to ignore this issue. Similarly, few researchers have addressed the health effects of across-time changes in job demands and control, in spite of the potential offered by such changes to increase our understanding of the effects of the work environment on health: Do changes in the work environment lead to subsequent interpretable across-time change in worker health?

Our study was designed to deal with these issues. Using data from a four-phase panel study among a sample of 824 Dutch workers, we examined and contrasted the effects of exposure to various combinations of job demands and control with respect to worker health. As such, this study aimed to contribute to our understanding of the effects of stability and change in job demands and job control on worker health.

\section{Longitudinal research on the effects of exposure to job demands and control on worker health}

There is some evidence that cumulative exposure to (a combination of) high demands and low control or a change towards high strain results in adverse health outcomes. Fenwick \& Tausig (13) have examined the effects of macroeconomic changes (such as recessions) on exposure to stress. They reported that higher unemployment rates increase stress and diminish job satisfaction via reduced decision latitude and increased job demands. Furthermore, Bourbonnais et al (14) found that cumulative exposure to high demands and low control across time is associated with higher psychological distress and emotional exhaustion than other types of work are. Furda et al (15) examined changes in the dimensions of the demand-control-support model and found significant main and interaction effects of adverse changes in demands and social support on health complaints and recovery complaints across time. They found no effects for control. Janssen \& Nijhuis (16) focused on positive changes in the dimensions of the demand-control-support model. They reported that positive changes resulted in lower levels of fatigue, emotional exhaustion, and psychological distress across time. De Jonge et al (17) examined the lagged effects of changes in these work characteristics on health as well. They found that an increase in work pressure was associated with increases in emotional exhaustion and depersonalization across time, whereas an increase in control was associated with an increase in job satisfaction. Finally, Theorell et al (18) looked at differences between work with high strain and work without high strain across time and found that total plasma testosterone levels increased when strain diminished in sedentary work.

The aforementioned studies suggest that (cumulative) exposure to a combination of high demands and low control affects health longitudinally. Yet none of the studies systematically contrasted the effects of stability and change in across-time exposure to demands and control. An exception to these studies is that of Schnall et al (19). These authors used an interesting way of analyzing stability and change in exposure by creating four "exposure profiles" (compare with reference 9), including two stable exposure profiles (ie, workers who were in the "high-strain" condition in both phases of their study and workers who were in the "no-highstrain" condition on both occasions) and two changing exposure profiles (ie, workers who changed from the "high-strain" condition to the "no-high-strain" condition, and vice versa). In line with the strain hypothesis of the demand-control model, those who were in the high-strain condition on both occasions reported the highest levels of ambulatory blood pressure. Furthermore, negative and positive changes in exposure to demands and control across time partially predicted negative and positive changes, respectively, in ambulatory blood pressure.

One important strength of the study of Schnall et al (19) was that it explicitly revealed the effects of cumulative exposure to high strain on worker health, in comparison with cumulative exposure to no high strain and two variations of noncumulative exposure to high 
strain. As such, their study demonstrated the detrimental effects of high job strain on worker health more clearly than any previous study had. However, this study (19) left several important questions unanswered as well. One issue concerns the fact that Schnall et al (19) distinguished between the "high-strain" versus "nohigh-strain" conditions only. Although this practice is consistent with Karasek's (1) juxtaposition of these two job types, it disregards the fact that the demand-control model includes passive and active job types as well. An interesting question, therefore, is whether more-detailed distinctions should be made within the cluster of nohigh-strain jobs, for example, does a change from the passive quadrant to the high-strain quadrant of Karasek's model (1) have the same effect on worker health as a change from the low-strain to the high-strain quadrant?

Another issue that would seem important is to examine whether subjectively experienced changes in the work environment, as studied by Schnall et al (19), have a basis in reality. Essentially, Karasek's (1) demandcontrol model is an environmental model in that it pretends to explain how the characteristics of the "objective" work environment affect worker well-being. Consequently, a second question would be whether changes in the work environment can be linked to changes in subjectively experienced work conditions and health outcomes. A positive answer to this question would strengthen the case for the reasoning that worker health is affected causally by characteristics of the work environment.

Finally, ambulatory blood pressure was the single outcome variable included in the Schnall et al study (19). Obviously, it is merely a single instance of a wider and more varied set of possible health outcomes, including subjective and "objective" health outcomes such as registered sickness absence and depression. It is therefore important to examine whether the findings of Schnall et al generalize to a wider set of outcome variables.

\section{Research questions and hypotheses}

In line with this reasoning, this paper addresses the following three core questions: (i) are Karasek's predictions for the differences in strain between the four different job types (high strain, low strain, active work, and passive work) supported for groups with stable exposure to demands and control, (ii) do positive (negative) changes in exposure to demands and control result in decreased (increased) strain levels across time, in agreement with the predictions of the demand-control model, and (iii) can change in reported exposure to demands and control be linked to "objective" changes in the work environment?
With respect to the first question, in line with the demand-control model, we expect cumulative high strain to result in diminished health across time because this type of job can be seen as a chronic stressor due to the low amount of control to "buffer" the effects of high job demands. Therefore, employees working in this type of job for a prolonged period will develop (symptoms of) diminished health, which reflects an unproductive and unhealthy response to the high demands (4, 20, 21). The lowest levels of strain are expected for the cumulative low-strain group. The other two Karasek job types (active versus passive work) are expected to take an intermediary position between the low- and high-strain groups in terms of levels of strain or health complaints. These expectations can be expressed in the following hypotheses: (i) employees with high demands and low control (high-strain jobs) on all occasions will report the highest level of strain when compared with the other three stable groups across time (hypothesis 1a), (ii) these employees will also report a significant increase in strain across time (hypothesis 1b), (iii) employees with low demands and high control (low-strain jobs) on all occasions will report the lowest level of strain when compared with the other three stable groups across time (hypothesis 2 a), (iv) these employees will also report a stable level of strain across time (hypothesis 2b), (v) employees with high demands and high control (active work) on all occasions will report an average level of strain when compared with the other three stable groups across time (hypothesis 3a), (vi) these employees will also report a stable level of strain across time (hypothesis $3 b$ ), (vii) employees with low demands and low control (passive work) on all four occasions will report an average level of strain when compared with the other three stable groups across time (hypothesis 4a), (viii) these employees will also report a stable level of strain across time (hypothesis $4 \mathrm{~b}$ ).

With respect to the second question, do positive (negative) changes in exposure to demands and control result in decreased (increased) strain levels across time, consistent with the predictions of the demand-control model, employees may change regarding their exposure to demands and control across time. In terms of Karasek's demand-control model, such changes can be for better or for worse (1). Positive changes include changes from a high-strain job to a low-strain job, changes from a high-strain job to an active or passive job, and changes from an active or passive job to a low-strain job. These changes are deemed positive because, according to the demand-control model, they should result in lower levels of health complaints. On the other hand, negative changes include changes from a low-strain, active, or passive job to a high-strain job, and changes from a low-strain job to an active or passive job. These changes should result in a higher number of health 
complaints. In accordance with this reasoning, the following hypotheses were developed: (ii) positive changes from a high-strain job to any no-high-strain job (ie, low-strain, active or passive work) will result in a significant decrease in strain across time (hypothesis 5), (ii) negative changes from any no-high-strain job to a high-strain job will result in a significant increase in strain across time (hypothesis 6), (iii) positive changes from active or passive work to a low-strain job will result in a significant decrease in strain across time (hypothesis 7), and (iv) negative changes from a low-strain job to active or passive work will result in a significant increase in strain across time (hypothesis 8).

For the third question, can change in reported exposure to demands and control be linked to "objective" change in the work environment, the studies that have examined the longitudinal effects of changes in exposure to demands and control have generally failed to explore the causes underlying change in self-reported exposure to demands and control (14-19, but see 13). The explanatory and dependent variables in these studies may therefore be confounded due to common method variance and related methodological artifacts and therefore make it virtually impossible to draw causal inferences (22). Therefore, it is important to examine the link between subjective and "objective" change in work characteristics more closely.

If Karasek's demand-control model (1) is indeed primarily an environmental model, one would expect that subjective changes in work characteristics would be accompanied by "objective" changes in the work environment (more specifically, by actual turnover). Conversely, the degree of turnover should be considerably lower if no such changes in subjective work characteristics occur. Thus we expect that groups reporting major changes in exposure to job demands and job control over time (ie, changes from a low-strain job to a high-strain job or vice versa) report more job changes than other groups (hypothesis 9).

\section{Subjects and methods}

\section{Sample}

Our study was conducted within the framework of the prospective Dutch cohort study on musculoskeletal disorders, absenteeism, stress, and health (SMASH) (2325). At the time of the baseline examination (in 1994), 1789 employees working in 34 companies, located throughout The Netherlands, participated in this study. Each year (up to 1997) the respondents received a selfadministered questionnaire that tapped concepts such as general work conditions, changes in the workplace, psy- chosocial work characteristics, work satisfaction, physical load at work, psychosocial and physical health, and background factors. Furthermore, information concerning registered sickness absence was annually obtained. [The design of the SMASH study is described in more detail in references 24 and 25.]

In order to be included, companies were required not to be involved in major reorganization during the 3 years of examination and that the prestudy annual turnover rate of their workforce be lower than $15 \%$. Furthermore, only respondents were selected who had been working for at least 1 year in their current job, for at least 20 hours per week. Both blue-collar jobs and white-collar jobs were included.

The data in this study are based on the annual questionnaires measuring psychosocial variables and the company-registered sickness absence data on four occasions (1994-1995-1996-1997). To ensure valid and reliable results, we excluded employees who had a temporary contract and employees receiving a benefit because of (partial) disability, 47 of the 1789 respondents therefore being excluded. The response rates were relatively high and varied between $84 \%(\mathrm{~N}=1742)$ in the baseline examination to $85 \%(\mathrm{~N}=1473)$ in the third follow-up measurement. An analysis of attrition revealed that dropouts tended to report more strain and less control across time, a common phenomenon (26). After listwise deletion of missing values, the sample included 1477 employees [ $70 \%$ men with an average age of 35.6 (SD 8.8) years at the time of the baseline examination and an average number of years of employment of 9.6 (SD 7.7) years].

\section{Measures}

Job demands. Job demands were measured using a fiveitem Dutch version of Karasek's (27) job content questionnaire. [Compare with reference 23, for example, "My job requires working very fast", $1=$ "strongly disagree", 4="strongly agree".] The reliability (Cronbach's alpha) of this scale varied from 0.65 to 0.72 across occasions (median alpha 0.71).

Job control. Consistent with Karasek's (27) conceptualization, job control was measured as the mean of two scales. Skill discretion was measured using a five-item scale (eg, "My job requires that I learn new things"), and decision authority was measured using a three-item scale (eg, "My job allows me to take many decisions on my own", 1="strongly disagree", 4="strongly agree"). The reliabilities of this scale ranged from 0.81 to 0.83 (median alpha 0.82).

Strain outcomes. The current study included four strain outcomes. Depression was measured on an 11-item Dutch version of the CES-D scale (Center for Epidemiological 
Studies Depression scale) $(28,29)$. This scale taps symptoms of depressive mood (eg, "The past two weeks I felt lonely", 1="hardly ever or never", 3="much or most of the time"). The reliability varied from 0.74 to 0.84 (median alpha $=0.77$ ) for this outcome. Job satisfaction was measured by a single item ("Do you mostly enjoy your work?", 1="strongly disagree", 4="strongly agree"). Obviously, the reliability of a single-item scale cannot be computed. However, a recent meta-analysis demonstrated that single-item measures of job satisfaction are usually highly correlated with multi-item scales (30). The duration of company-registered sickness absence was measured as the period of days of sickness absence registered in the past year. Annually, the companies registered the date of the onset and the end of each period of sickness absence. From this information the frequency of sickness absence was also derived. The frequency of company-registered sickness absence refers to the number of sickness spells that began and ended in the past year. The distributions of the sickness absence variables were positively skewed. Consequently, they were square-root transformed to obtain more normally distributed variables.

Covariates. Age, level of education, gender, and years of work experience were used as covariates in the analysis, because these variables are often related to the outcome variables employed in this study. Therefore, failing to control for these variables may have resulted in distortion of the effects of the other variables $(4,5,11)$.
Job change. On all four occasions of the study, the employees were asked whether the employees had changed jobs over the preceding 12 months and whether this change had given them distress (categories were "no job change", "job change, not distressing", "job change, rather distressing", "job change, very distressing"). The last two categories were collapsed, yielding a three-category variable ("no job change", "job change, not distressing", and "job change, distressing"). Then the three occasions were combined into a single variable that reflected whether the employees had experienced at least one job change during the 3-year interval between the first and last phase of the study and, if so, whether this change was distressing. Of the employees, $74.0 \%$ had not experienced a job change, $20.8 \%$ had experienced a no distressing job change (neutral or positive), and 5.2\% reported at least one distressing job change (negative).

\section{Correlation analysis}

Table 1 presents the means, standard deviations, and correlations between the different measures at the time of the baseline examination. The correlations between the dependent and independent measures were in the expected direction, except that job demands did not significantly correlate with sickness absence (neither with absence duration nor absence frequency). As regards the across-time stability of these variables, the time 1-time 2 test-retest correlations ranged from 0.42 (sickness absence duration) to 0.65 (for control), the median

Table 1. Means, standard deviations, and correlations of all the variables as measured the time of the baseline examination (listwise deletion of missing data, $\mathrm{N}=1477) .{ }^{\mathrm{a}}$ ( $\mathrm{SD}=$ standard deviation)

\begin{tabular}{|c|c|c|c|c|c|c|c|c|c|c|c|c|}
\hline & \multirow[b]{2}{*}{ Mean } & \multirow[b]{2}{*}{ SD } & \multicolumn{10}{|c|}{ Variable } \\
\hline & & & 1 & 2 & 3 & 4 & 5 & 6 & 7 & 8 & 9 & 10 \\
\hline 1. Gender b & 0.70 & 0.50 & 1.00 & & & & & & & & & \\
\hline 2. Age & 35.57 & 8.76 & -0.15 & 1.00 & & & & & & & & \\
\hline 3. Education ${ }^{\mathrm{c}}$ & 2.65 & 1.10 & 0.13 & -0.07 & 1.00 & & & & & & & \\
\hline 4. Years of experience & 9.56 & 7.72 & -0.20 & 0.59 & -0.18 & 1.00 & & & & & & \\
\hline 5. Demand & 2.60 & 0.45 & 0.04 & 0.02 & 0.03 & 0.02 & 1.00 & & & & & \\
\hline 6. Control & 2.82 & 0.49 & -0.19 & 0.11 & 0.22 & 0.11 & -0.05 & 1.00 & & & & \\
\hline 7. Depression & 1.27 & 0.27 & 0.11 & -0.01 & -0.02 & -0.03 & 0.13 & -0.16 & 1.00 & & & \\
\hline 8. Job satisfaction & 3.35 & 0.72 & 0.11 & 0.04 & -0.04 & 0.03 & -0.09 & 0.28 & -0.19 & 1.00 & & \\
\hline 9. Sickness absence (duration) & 22.98 & 42.10 & 0.11 & -0.02 & -0.16 & 0.06 & 0.04 & -0.11 & 0.17 & -0.02 & 1.00 & \\
\hline 10. Sickness absence (frequency) & 1.72 & 1.73 & 0.14 & -0.15 & 0.01 & -0.11 & 0.05 & -0.11 & 0.16 & -0.09 & 0.70 & 1.00 \\
\hline
\end{tabular}

a Correlations of 0.05 and over are significant at $\mathrm{P}<0.05$, correlations of 0.09 and over are significant at $\mathrm{P}<001$.

b $0=$ female and $1=$ male.

c 1 = primary education or lower, 2 = lower vocational education, 3 = secondary education or middle vocational education, $4=$ higher vocational education, 5 = college or university education. 
correlation being 0.51 (all $\mathrm{P}$ values $<0.001$ ). The time 1-time 4 test-retest correlations ranged from 0.27 (sickness absence duration) to 0.42 (job control), the median correlation being 0.45 (all $\mathrm{P}$ values $<0.001$ ). Although these correlations were substantial, it was also clear that there was some across-time variation in the concepts included in this study. For example, a time 1-time 2 correlation of 0.65 for control implies that both measures shared roughly only $42 \%(0.65 \times 0.65 \times 100)$ of their variance. After correction for measurement error by dividing the observed correlation of 0.65 by the reliability of the measures (ie, the median alpha for this concept of 0.82$)$, this figure increased to $62 \%(0.79 \times 0.79$ $\times 100$ ) of the shared variance. Thus, even in the most optimistic case (high time 1-time 2 correlations and correction for attenuation), about $40 \%$ of the variance in time 2 remained unaccounted for. This occurrence suggested that, in examinations of the longitudinal effects of job demands and job control on worker health, it may be necessary to include information concerning change on these aspects in the analysis. The following discussion presents one way of accomplishing this inclusion.

\section{Creation of demand-control histories}

Eleven groups were created on the basis of their exposure to different combinations of job demand and control. First, all the variables measuring job demand and job control in each of the four phases of this study were dichotomized using a median split procedure. Within each measurement, and consistent with the ideas of Karasek (1), four job demand-job control combinations were formed. As this study included four phases, theoretically four (4 demand-control combinations) to the fourth power (4 phases) equals 256 different demandcontrol histories could be distinguished. Four of these consisted of stable histories (ie, in which no transition from one quadrant to another was observed on the four occasions (numbers varying from 61 for the stable highstrain group to 108 for the stable low-strain group). (See table 2.)

Groups 5-10 consisted of employees whose demandcontrol histories included one transition across time. The timing of the transition was deemed irrelevant. Group 5 included demand-control histories in which the employees were initially in the low-strain quadrant and later moved to the high-strain quadrant $(\mathrm{N}=8)$. A low incidence of this pattern was expected, as this transition presents a major change in (the perception of) one's job characteristics. Similarly, group 6 consisted of employees who moved from the high-strain to the low-strain quadrant $(\mathrm{N}=12)$, another major change, coinciding with a low frequency of occurrence. Group 7 included employees who changed from the active or passive quadrant to the low-strain quadrant $(\mathrm{N}=71)$. Group 8 was comprised of employees who changed from the lowstrain quadrant to the active or passive quadrant $(\mathrm{N}=171)$. Group 9 consisted of employees who moved from active or passive work to the high-strain quadrant $(\mathrm{N}=76)$. Group 10 included those who moved from the high-strain quadrant to the active or passive quadrant $(\mathrm{N}=123)$.

The eleventh group consisted of the 653 subjects (44\%) whose demand-control histories included more than a single transition. These relatively complex and ambiguous histories could not be classified theoretically and were omitted from the analysis. Consequently, this manuscript presents the results of a total of 824 respondents.

\section{Statistical analyses}

To answer our first and second questions, we analyzed the data using a 10 (group: the 4 with stable and the 6 with changing demand-control history) $\times 4$ (time: 4 occasions) analysis of variance (ANOVA) with time as a within-participants factor and group as a between-participants factor. For simplicity the employees' scores for depression, job satisfaction, sickness absence duration, and sickness absence frequency were analyzed separately.

To obtain more insight into the nature of the association between the frequency and valence of job change and different demand-control histories (third question), two log-linear analyses were conducted $(31,32)$. As in ordinary cross-table analyses, the log-linear analysis examines the strength of associations between two (or more) qualitative variables. However, log-linear analyses foster an understanding of possible associations between variables by providing statistical tests that show which elements of a two-way cross table are responsible

Table 2. Description of the demand-control histories.

\begin{tabular}{clr}
\hline $\begin{array}{l}\text { Group } \\
\text { number }\end{array}$ & Group label & N \\
\hline 1. & Stable high strain (no across-time change) & 61 \\
2. & Stable low strain (no across-time change) & 108 \\
3. & Stable active (no across-time change) & 97 \\
4. & Stable passive (no across-time change) & 93 \\
5. & Change from low strain to high strain & 8 \\
6. & Change from high strain to low strain & 12 \\
7. & Change from active or passive to low strain & 71 \\
8. & Change from low strain to active or passive & 171 \\
9. & Change from active or passive to high strain & 76 \\
10. & Change from high strain to active or passive & 123 \\
& Total & 824 \\
\hline 11. & Other (ambiguous demand-control histories \\
& with >1 change in job characteristics; omitted from & 653 \\
& further analysis) & \\
& Total & 1477 \\
\hline
\end{tabular}

Scand J Work Environ Health 2002, vol 28, no 2 
for the association. To this aim, log-linear analysis distinguishes between main effects and interaction effects. A main effect can be interpreted as indicating the difference between the expected cell frequency for this variable and the observed cell frequency. Log-linear analysis provides a statistical test for each category of this variable and shows whether the number of observations in this category deviates significantly from what would be expected for this category. An interaction effect between two variables can be understood in a similar fashion: for all cells of a two-way cross-tabulation, it presents the deviation between what would be expected for this cell and the actual number of observations in the cell, the net of the main effects of the two constituent variables. Log-linear effect parameters are actually computed in a rather sophisticated manner (31), but this basic introduction suffices to understand the results of our analyses.

\section{Results}

\section{Comparison of means in the preliminary analysis}

Table 3 presents the means and standard errors of the outcome variables as a function of time and group. As this table reveals, there were significant main effects of time for depression $[\mathrm{F}(3,601)=12.31, \mathrm{P}<0.01]$, job satisfaction $[\mathrm{F}(3,489)=2.68, \mathrm{P}<0.05]$, and sickness absence duration $[\mathrm{F}(3,583)=3.05, \mathrm{P}<0.05]$. The findings were highly similar across these three variables in that the scores tended to become more unfavorable across time (ie, more depression and longer average sickness absence duration, lower job satisfaction). For sickness absence frequency no main effect of time was observed $[F(3,583)=2.21$, not significant $]$.

The main effects of the group were found for depression $[\mathrm{F}(9,603)=7.89, \mathrm{P}<0.01]$, job satisfaction $[\mathrm{F}$ $(9,491)=13.99, \mathrm{P}<0.01]$, sickness absence duration $[\mathrm{F}$ $(9,585)=5.53, P<0.01]$, and sickness absence frequency $[\mathrm{F}(9,585)=3.41, \mathrm{P}<0.01]$. The pattern of effects was similar across groups, with groups 1 (stable high strain), 5 (low strain to high strain), and 10 (high strain in active or passive job) reporting the most negative outcomes in terms of depression, job satisfaction, sickness absence duration, and sickness absence frequency and groups 2 (stable low strain), 7 (active or passive to low strain), and 8 (low strain in active or passive job) reporting relatively the most favorable health outcomes.

Significant interaction effects between time and group were found for depression $[F(27,1809)=1.65$,

Table 3. Means and standard errors (SE) of the outcome variables as a function of time and group. (NS = not significant)

\begin{tabular}{|c|c|c|c|c|c|c|c|c|}
\hline & \multicolumn{6}{|c|}{ Variable } & & \\
\hline & \multirow{2}{*}{\multicolumn{2}{|c|}{ Depression }} & \multirow{2}{*}{\multicolumn{2}{|c|}{ Job satisfaction }} & \multicolumn{4}{|c|}{ Sickness absence a } \\
\hline & & & & & \multicolumn{2}{|c|}{ Duration } & \multicolumn{2}{|c|}{ Frequency } \\
\hline & Mean & SE & Mean & SE & Mean & SE & Mean & SE \\
\hline \multicolumn{9}{|l|}{ Time } \\
\hline Time 1 & 1.27 & 0.01 & 3.34 & 0.04 & 18.62 & 2.08 & 1.80 & 0.10 \\
\hline Time 2 & 1.34 & 0.02 & 3.32 & 0.04 & 23.32 & 2.65 & 1.97 & 0.10 \\
\hline Time 3 & 1.36 & 0.02 & 3.23 & 0.05 & 24.79 & 3.14 & 1.77 & 0.11 \\
\hline Time 4 & 1.38 & 0.02 & 3.25 & 0.05 & 30.66 & 3.79 & 1.69 & 0.18 \\
\hline \multicolumn{9}{|l|}{ Group (demand-control history) } \\
\hline 1: stable high strain & 1.42 & 0.03 & 2.79 & 0.07 & 36.67 & 4.31 & 2.12 & 0.18 \\
\hline 2: stable low strain & 1.19 & 0.02 & 3.61 & 0.06 & 18.50 & 3.28 & 1.39 & 0.14 \\
\hline 3: stable active & 1.33 & 0.03 & 3.46 & 0.08 & 17.46 & 4.40 & 1.37 & 0.19 \\
\hline 4: stable passive & 1.31 & 0.02 & 3.16 & 0.06 & 24.16 & 3.36 & 1.53 & 0.15 \\
\hline 5: change from low strain to high strain & 1.57 & 0.08 & 3.20 & 0.24 & 30.70 & 13.77 & 2.79 & 0.57 \\
\hline 6: change from high strain to low strain & 1.34 & 0.07 & 3.41 & 0.16 & 11.83 & 9.74 & 1.44 & 0.40 \\
\hline 7: change from active or passive to low strain & 1.24 & 0.03 & 3.56 & 0.07 & 19.77 & 4.15 & 1.67 & 0.18 \\
\hline 8: change from low strain to active or passive & 1.25 & 0.02 & 3.49 & 0.06 & 19.01 & 2.82 & 1.77 & 0.12 \\
\hline 9: change from active or passive to high strain & 1.34 & 0.03 & 3.08 & 0.07 & 27.58 & 4.08 & 1.97 & 0.18 \\
\hline 10: change from high strain to active or passive & 1.39 & 0.03 & 3.09 & 0.09 & 37.78 & 3.51 & 2.01 & 0.15 \\
\hline \multicolumn{9}{|l|}{ MANOVA F-values } \\
\hline Time & \multicolumn{2}{|c|}{$\mathrm{F}(3,601)=12.31^{\star *}$} & \multicolumn{2}{|c|}{$F(3,489)=2.68^{*}$} & \multicolumn{2}{|c|}{$F(3,583)=3.05^{\star}$} & \multicolumn{2}{|c|}{$\mathrm{F}(3,583)=2.21, \mathrm{NS}$} \\
\hline Group & \multicolumn{2}{|c|}{$F(9,603)=7.89^{* *}$} & \multicolumn{2}{|c|}{$F(9,491)=13.99^{\star \star}$} & \multicolumn{2}{|c|}{$F(9,585)=5.53^{\star *}$} & \multicolumn{2}{|c|}{$F(9,585)=3.41^{\star \star}$} \\
\hline Time $x$ group & \multicolumn{2}{|c|}{$F(27,1809)=1.65^{\star}$} & \multicolumn{2}{|c|}{$F(27,1473)=1.79^{* *}$} & \multicolumn{2}{|c|}{$F(27,1755)=0.88, N S$} & \multicolumn{2}{|c|}{$F(27,1755)=1.18, N S$} \\
\hline
\end{tabular}

a F-values for sickness absence duration and frequency are based on square-root transformed means.

${ }^{*} \mathrm{P}<0.05$, ${ }^{* *} \mathrm{P}<0.01$. 
$\mathrm{P}<0.05]$ and job satisfaction $[\mathrm{F}(27,1473)=1.79$, $\mathrm{P}<0.01]$. [The means for these interaction effects are not shown in table 3.] For the two "objective" health indicators (sickness absence duration and sickness absence frequency), no significant interaction effects were found. The interaction effects for depression and job satisfaction are discussed later in conjunction with the discussion of the hypotheses of this study.

\section{Differences among stable exposure groups (question 1, hypotheses 1-4)}

Figure 1 presents the relevant means for the stable exposure groups for depression and job satisfaction. For depression, a group (demand-control histories 1-4) by time (4 occasions) ANOVA with planned contrasts on time revealed the main effects of time $[\mathrm{F}(3,308)=6.14$, $\mathrm{P}<0.05]$ and group $[\mathrm{F}(3,310)=15.12, \mathrm{P}<0.01]$. These main effects were further qualified by a group-by-time interaction effect $[F(9,930)=1.08, P<0.01]$. For job satisfaction similar results were obtained: main effects of time $[\mathrm{F}(3,252)=3.32, \mathrm{P}<0.05]$ and group $[\mathrm{F}(3$, $254)=29.12, \mathrm{P}<0.01]$ and a group-by-time interaction effect $[\mathrm{F}(9,762)=2.39, \mathrm{P}<0.05]$. Tukey's least significant difference (LSD) test revealed that, compared with the other stable groups, the respondents in the stable high-strain group reported the highest level of depression and lowest level of job satisfaction across time (hypothesis 1a supported). Furthermore, the respondents in the low-strain group reported the lowest levels of depression and the highest levels of job satisfaction, except for when compared with the stable active group in the measurement of job satisfaction (hypothesis 2a partially supported). The active-passive workers showed more or less average results (hypotheses $3 \mathrm{a}$ and $4 \mathrm{a}$ supported).

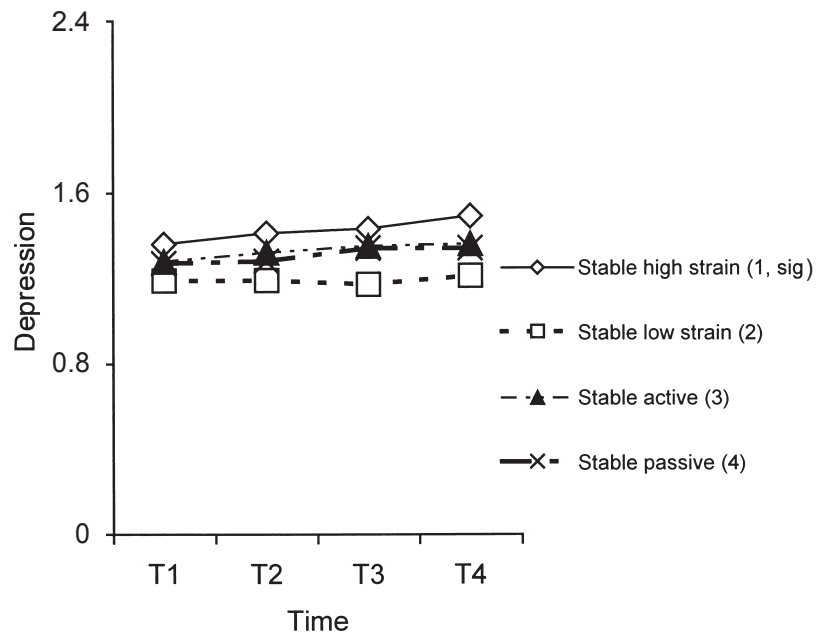

As expected, for the high-strain group, levels of depression (job satisfaction) increased (decreased) significantly $[\mathrm{F}(3,57)=2.92, \mathrm{P}<0.05$ and $\mathrm{F}(3,48)=5.16$, $\mathrm{P}<0.01$, respectively] (hypothesis $1 \mathrm{~b}$ supported). For the three other stable groups no across-time change was observed (hypotheses $2 \mathrm{~b}, 3 \mathrm{~b}, 4 \mathrm{~b}$ supported).

\section{Changing exposure groups (question 2, hypotheses 5-8)}

Figure 2 presents the relevant means for the changing exposure groups for depression and job satisfaction. For depression, a group (demand-control history 5-10) by time (4 occasions) ANOVA with planned contrasts as to time revealed main effects for time $[\mathrm{F}(3,291)=8.51$, $\mathrm{P}<0.01]$ and group $[\mathrm{F}(5,293)=5.39, \mathrm{P}<0.01]$. Furthermore, there was a group-by-time interaction effect $[F(15,879)=1.99, P<0.05]$. For job satisfaction a main effect of group $[\mathrm{F}(5,237)=7.51, \mathrm{P}<0.01]$ was obtained, as well as a group-by-time interaction effect $[\mathrm{F}(15$, 711) $=1.71, \mathrm{P}<0.05]$.

Analyses for the exposure groups separately revealed the following for the hypotheses for the changing exposure groups. First, only partial support was found for hypothesis 5 . The change from high strain to active or passive work (group 10) was only significant for the dependent variable job satisfaction $[F(3,35)=3.22$, $\mathrm{P}<0.05]$. No significant results were found for depression or for the change from high strain to low strain (group 6). Second, the results for the changing exposure groups also provided only partial support for hypothesis 6 . Only the change from low strain to high strain (group 5) was associated with a significant increase in depression $[\mathrm{F}(3,5)=9.32, \mathrm{P}<0.05]$, but not with a significant decrease in job satisfaction across time. The

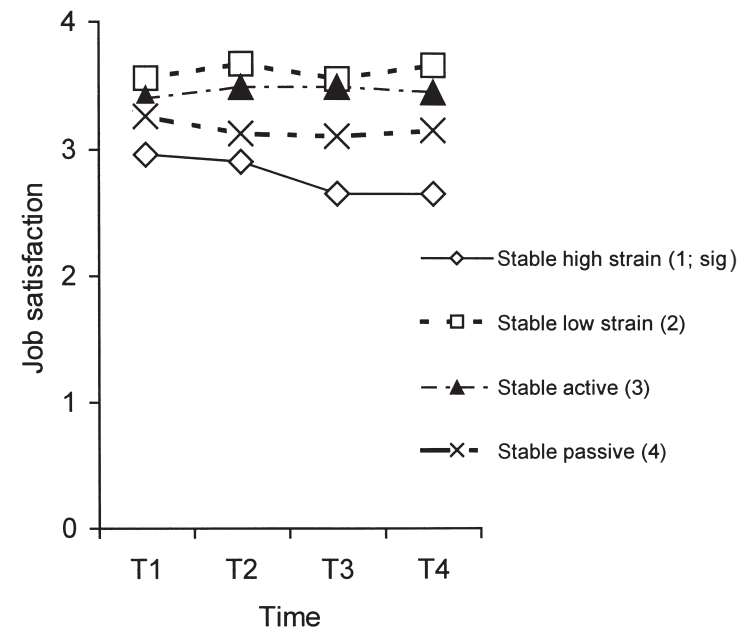

Figure 1. Changes in depression (left) and job satisfaction (right) for the four stable exposure groups (stable demand-control histories). (sig: significant time effect) 

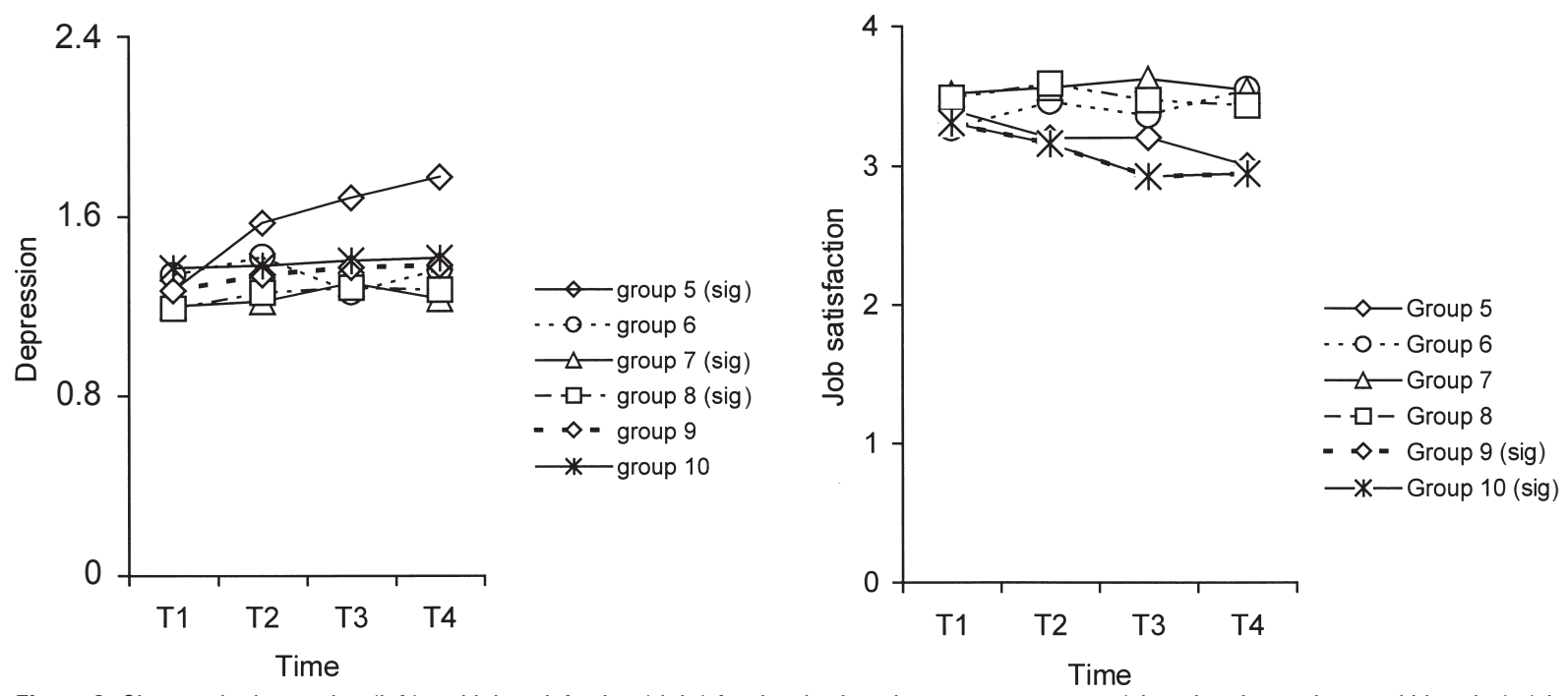

Figure 2. Changes in depression (left) and job satisfaction (right) for the six changing exposure groups (changing demand-control histories). (sig $=$ significant time effect, group $5=$ change from low strain to high strain, group $6=$ change from high strain to low strain, group $7=$ change from active or passive to low strain, group $8=$ change from low strain to active or passive, group $9=$ change from active or passive to high strain, group $10=$ change from high strain to active or passive)

Table 4. Frequency of job change as a function of demand-control history and type of change.

\begin{tabular}{|c|c|c|c|c|c|c|c|c|}
\hline \multirow[t]{3}{*}{ Demand-control history } & \multicolumn{6}{|c|}{ Job change } & & \\
\hline & \multicolumn{2}{|c|}{ None } & \multicolumn{2}{|c|}{ Neutral or positive } & \multicolumn{2}{|c|}{ Negative } & \multicolumn{2}{|c|}{ Total } \\
\hline & $\mathrm{N}$ & $\%$ & $\mathrm{~N}$ & $\%$ & N & $\%$ & $\mathrm{~N}$ & $\%$ \\
\hline 1. Stable high strain & 47 & 77.0 & 7 & 11.5 & 7 & 11.5 & 61 & 7.4 \\
\hline 2. Stable low strain & 75 & 69.4 & 29 & 26.9 & 4 & 3.7 & 108 & 13.1 \\
\hline 3. Stable active & 80 & 82.5 & 15 & 15.5 & 3 & 3.1 & 97 & 11.8 \\
\hline 4. Stable passive & 74 & 79.6 & 17 & 18.3 & 2 & 2.2 & 93 & 11.3 \\
\hline 5. Change from low strain to high strain & 2 & 25.0 & 4 & 50.0 & 2 & 25.0 & 8 & 1.0 \\
\hline 6. Change from high strain to low strain & 5 & 41.7 & 5 & 41.7 & 2 & 16.7 & 12 & 1.5 \\
\hline 7. Change from active or passive to low strain & 45 & 63.4 & 21 & 29.6 & 5 & 7.0 & 71 & 8.6 \\
\hline 8. Change from low strain to active or passive & 134 & 78.4 & 33 & 19.3 & 7 & 4.1 & 171 & 20.8 \\
\hline 9. Change from active or passive to high strain & 55 & 72.4 & 15 & 19.7 & 6 & 7.9 & 76 & 9.2 \\
\hline 10. Change from high strain to active or passive & 93 & 75.6 & 25 & 20.3 & 5 & 4.1 & 123 & 14.9 \\
\hline Total & 610 & 74.0 & 171 & 20.8 & 43 & 5.2 & 824 & 100.0 \\
\hline
\end{tabular}

Chi-square $(18, \mathrm{~N}=824)=41.1, \mathrm{P}<0.01$.

change from active or passive work to high strain (group 9) was associated with a significant increase in job satisfaction $[\mathrm{F}(3,48)=6.46, \mathrm{P}<0.01]$ but not with a significant decrease in depression across time. Finally, hypotheses 7 and 8 were supported for depression only. The change from active or passive work to low strain (group 7) was associated with a significant decrease in depression across time $[\mathrm{F}(3,57)=3.77, \mathrm{P}<0.05]$, whereas the change from low strain to active or passive work (group 8) was associated with a significant increase in depression $[\mathrm{F}(3,100)=5.38, \mathrm{P}<0.01]$. These changing exposure groups showed no significant changes in job satisfaction.

\section{Possible link between subjective and "objective" job changes (question 3, hypothesis 9)}

Table 4 presents the frequency of job change as a function of demand-control history and type of change. ${ }^{4} \mathrm{~A}$ distinction was made among the three categories: "no job change" versus "job change, not distressing" versus "job change, distressing". Table 4 reveals that the 
number and types of job change differed strongly across the groups, as evidenced by a significant association between demand-control history and type of change [chi-square $(8, \mathrm{~N}=824)=41.04, \mathrm{P}<0.01]$.

Type of demand-control history and job change. Two log-linear analyses were conducted. In the first, the association between demand-control history and job change (no change versus change) was examined. For simplicity, and to obtain reasonably large cell frequencies, we collapsed across demand-control histories and obtained a trichotomous qualitative variable. The four stable demand-control histories were included in the first category. Relatively few job changes were expected for them, as there was no change in the job characteristics. The second category comprised the two demand-control histories in which a major change in job characteristics had occurred [ie, a change from low strain to high strain or from high strain to low strain (demand-control histories 5 and 6, respectively, as shown in table 2)]. As the characteristics of the work environment seemed to have changed strongly for these two demand-control histories, we expected a relatively high number of job changes for this category. The remaining demand-control histories (demand-control histories 7-10 in table 2) were assigned to the third category. This category was expected to take an intermediary position between the other two categories in terms of frequency of job change.

Table 5 presents the relevant cell frequencies and the results of the first log-linear analysis. As this table shows, $74.0 \%$ of the employees did not report any job change, while the remaining $26.0 \%$ did. The corresponding log-linear effect parameters were 0.27 (there were more employees in the "no job change" category than expected) and -0.27 (there were fewer employees than expected in this category) (P-values $<0.001$, respectively). Similarly, the employees were not evenly distributed across type of demand-control history. There were more employees than expected in the stable category (demand-control histories 1-4 in table 2) and the category with a minor demand-control history (positive loglinear parameters for these two categories, see table 5), whereas relatively few employees were categorized as having a major change in their demand-control histories (only $2.4 \%$, a negative effect parameter of -1.93 , $\mathrm{P}<0.001)$.

According to hypothesis 9, demand-control histories involving a major change in work characteristics should show more job changes than the other demand-control histories. As expected, there was a statistically significant association between type of demand-control history and job change [chi-square ( $2 \mathrm{df}, \mathrm{N}=824)=17.2$, $\mathrm{P}<0.001]$. As expected, closer inspection of table 5 reveals that this interaction is due to the fact that the group with a major change in their demand-control history reported relatively many job changes (65.0\% reporting at least one job change), whereas the other two categories of demand-control history were more or less similar. [About a quarter of the respondents in these categories reported a job change, and thus hypothesis 9 received support.] Indeed, the follow-up analysis revealed that the association between type of demand-control history and job change disappeared when the category of major change in demand-control history was omitted from the analysis [chi-square $(\mathrm{df}=1, \mathrm{~N}=804)=0.97$, not significant] and showed that the stable group and minor change group for demand-control history did not differ significantly in terms of their levels of (self-reported) turnover.

Valence of job change and demand-control history. In addition, table 6 presents the results of a second exploratory log-linear analysis dealing with the association between the valence of job change and the valence of the demand-control histories. As noted earlier, the employees not only reported whether they had changed jobs, but they also indicated whether they found this

Table 5. Associations between type of demand-control history and job change. The demand-control history groups correspond with those presented in table 2.

\begin{tabular}{|c|c|c|c|c|c|c|c|c|c|}
\hline \multirow{3}{*}{$\begin{array}{l}\text { Type of demand-control } \\
\text { history }\end{array}$} & \multicolumn{9}{|c|}{ Job change } \\
\hline & \multicolumn{3}{|c|}{ No change } & \multicolumn{3}{|c|}{ Change } & \multicolumn{3}{|c|}{ Total } \\
\hline & $\mathrm{N}$ & $\%$ & $\begin{array}{l}\text { Log-linear } \\
\text { effect } \\
\text { parameter }\end{array}$ & N & $\%$ & $\begin{array}{l}\text { Log-linear } \\
\text { effect } \\
\text { parameter }\end{array}$ & $\mathrm{N}$ & $\%$ & $\begin{array}{l}\text { Log-linear } \\
\text { effect } \\
\text { parameter }\end{array}$ \\
\hline Stable (groups 1-4) & 276 & 76.7 & $0.33^{\star \star \star}$ & 84 & 23.3 & $-0.33^{\star \star}$ & 360 & 43.7 & $0.84^{\star \star \star}$ \\
\hline Major change (groups 5-6) & 7 & 35.0 & $-0.58^{\star \star *}$ & 13 & 65.0 & $0.58^{\star \star \star}$ & 20 & 2.4 & $-1.93^{\star * *}$ \\
\hline Minor change (groups $7-10$ ) & 327 & 73.6 & $0.25^{\star \star}$ & 117 & 26.4 & $-0.25^{\star \star}$ & 444 & 53.9 & $1.09^{\star * *}$ \\
\hline Total & 610 & 74.0 & $0.27^{\star \star}$ & 214 & 26.0 & $-0.27^{\star *}$ & 824 & 100.0 & \\
\hline
\end{tabular}

Chi-square $(2, N=824)=17.2^{* * *}$

${ }^{*} \mathrm{P}<0.05,{ }^{* *} \mathrm{P}<0.01,{ }^{* *} \mathrm{P}<0.001$. 
Table 6. Associations between the valence of demand-control history and the valence of type of change. The demand-control history groups correspond with those presented in table 2.

\begin{tabular}{|c|c|c|c|c|c|c|c|c|c|}
\hline \multirow{3}{*}{$\begin{array}{l}\text { Valence of demand-control } \\
\text { history }\end{array}$} & \multicolumn{9}{|c|}{ Valence of change } \\
\hline & \multicolumn{3}{|c|}{ Neutral or positive } & \multicolumn{3}{|c|}{ Negative } & \multicolumn{3}{|c|}{ Total } \\
\hline & N & $\%$ & $\begin{array}{l}\text { Log-linear } \\
\text { effect } \\
\text { parameter }\end{array}$ & N & $\%$ & $\begin{array}{l}\text { Log-linear } \\
\text { effect } \\
\text { parameter }\end{array}$ & $\mathrm{N}$ & $\%$ & $\begin{array}{l}\text { Log-linear } \\
\text { effect } \\
\text { parameter }\end{array}$ \\
\hline Neutral (groups 2-4, 7-8) & 115 & 84.6 & $0.23^{\star}$ & 21 & 15.4 & $-0.23^{*}$ & 136 & 63.5 & $0.71^{\star \star \star}$ \\
\hline Negative (groups 1, 5, 9) & 26 & 63.4 & $-0.34^{*}$ & 15 & 36.6 & $0.34^{\star}$ & 41 & 19.2 & -0.20 \\
\hline Positive (groups 6, 10) & 30 & 81.0 & 0.11 & 7 & 19.0 & -0.11 & 37 & 17.3 & $-0.51^{\star \star \star}$ \\
\hline Total & 171 & 79.9 & $0.62^{\star \star \star}$ & 43 & 20.1 & $-0.62^{\star \star \star}$ & 214 & 100.0 & \\
\hline
\end{tabular}

Chi-square $(2, N=214)=8.8^{*}$

${ }^{*} \mathrm{P}<0.05,{ }^{* *} \mathrm{P}<0.01,{ }^{* * *} \mathrm{P}<0.001$.

change distressing (valence: no distressing job change versus distressing job change). Furthermore, according to the ideas of Karasek (1), demand-control histories that included a job change towards the high-strain category (demand-control histories 5 and 9) and the stable highstrain demand-control history (demand-control history 1) were denoted as "negative". Accordingly demandcontrol histories that included a job change out of the high-strain category were considered "positive" (demand-control histories 6 and 10). The remaining demand-control histories were denoted as "neutral". Note that this analysis included only the employees who reported at least one job change. Note also that this analysis was statistically independent of the previous loglinear analysis: knowing that one has changed jobs is not in any way informative concerning the direction of this change.

Again, the employees were not evenly distributed across the categories of the valence of job change and the valence of demand-control history. More importantly, there was a significant association between these two variables [chi-square $(\mathrm{df}=2, \mathrm{~N}=214)=8.8, \mathrm{P}<0.05]$. Closer inspection of the interaction revealed that about onethird of the employees in the negative categories of demand-control history (36.6\%) experienced their job change as negative (or distressing), as compared with $15.4 \%$ in the neutral category of demand-control history and $19.0 \%$ in the positive category. Again, omitting the negative group from the analysis resulted in a nonsignificant association between the valence of job change and the valence of the demand-control history category [chi-square $(\mathrm{df}=1, \mathrm{~N}=173)=0.26$, not significant]. This result shows that the negative category of demand-control history deviated strongly from the two other categories.

In summary, these results indicate (i) that workers reporting major changes in demand-control histories across time also experience more "objective" job changes when compared with workers who report less dramatic changes in their demand-control histories and (ii) that job changes towards high strain are also evaluated by workers as more distressful (hypothesis 9 supported).

\section{Discussion}

In our study we examined the effects of exposure to various combinations of job demands and job control in the context of a four-phase study among 824 Dutch workers. Consistent with the notions first outlined by Karasek (1), in each phase, we distinguished between high-strain jobs, low-strain jobs, active jobs, and passive jobs. Building on previous work by Schnall et al (19), we developed a classification of 10 theoretically distinct across-time demand-control histories or "exposure profiles" (9). For each of these demand-control histories explicit hypotheses were formulated concerning their across-time development in terms of "subjective" and "objective" health outcomes. By contrasting the obtained scores, we aimed at promoting our understanding of the across-time health effects of exposure to various combinations of job demands and job control. For convenience, table 7 presents a summary of the hypotheses tested in this study.

\section{Are Karasek's predictions of the strain differences between the four different job types supported for groups with stable exposure to demands and control?}

As expected, the highest levels of strain were reported for the stable high-strain jobs, whereas, for the stable low-strain jobs, relatively little strain was reported. Furthermore, the employees with a stable high-strain demand-control history reported increasing strain across time, while there were no such time effects for the other three stable demand-control histories. Thus the adverse effects of high strain tended to become more pronounced across time. Note, however, that these positive findings apply to depression and job satisfaction only; 
for the two sickness absence measures (sickness absence frequency or duration) the hypotheses were largely rejected. [See the discussion that follows.]

\section{Do positive (negative) changes in exposure to demands and control result in decreased (increased) strain levels across time?}

Generally, we expected that positive (negative) changes in terms of job demands and job control would be associated with correspondingly lower (higher) levels of strain. Table 7 shows that this basic hypothesis received moderate support at best. None of the specific hypotheses were supported for the two sickness absence measures. Results were mixed for the two other outcome variables. Hypothesis 5 stated that a change from a highstrain job to a no-high-strain job would be associated with an increase in well-being. This hypothesis was supported for job dissatisfaction only, and even then for high strain in the active or passive groups only (hypothesis 5 partially supported). Hypothesis 6 stated that a change from a no-high-strain job to a high-strain job would result in a significant increase in strain. This hypothesis was supported for depression and job dissatisfaction: changes from low strain to high strain and from active or passive work to high strain were indeed associated with elevated levels of ill health. This pattern of results suggests that a change from the no-high-strain condition to the high-strain condition tends to result in elevated levels of self-reported strain. However, the corresponding positive change (ie, from the high-strain condition to the low-strain condition) seems to have much weaker effects on levels of strain. This finding suggests that the adverse effects of having a high-strain job are such that they are not resolved immediately when positive changes occur - an "accumulation effect" in Frese \& Zapf's terminology (12).

Hypothesis 7 stated that a change from active or passive work to low strain would be associated with lower levels of strain, whereas the reverse change (from lowstrain to active or passive work) would be associated with increasing levels of strain (hypothesis 8). These hypotheses were supported for depression only. Thus it is not the case that the possible detrimental health effects of a prolonged period in an active or passive job are such that they are not resolved soon after a change to a healthier job. This finding is consistent with Karasek's (1) position that especially a high-strain job has detrimental effects on health, and that these health effects would be less pronounced for the other three job types.

\section{Can change in reported exposure to demands and control be linked to "objective" changes in the work environment?}

As Karasek's (1) demand-control model is environmental in nature, it is important to check whether subjectively reported changes in work characteristics can be linked to "objective" changes in the work environment. In our study significant associations were found between changes in the demand-control histories and self-reported job changes over time. Furthermore, we found that employees who reported negative changes in self-reported job conditions were more likely to have experienced

Table 7. Summary of support of the hypotheses.

\begin{tabular}{|c|c|c|c|c|c|}
\hline & & \multicolumn{4}{|c|}{ Outcome variables ${ }^{a}$} \\
\hline & & \multirow{2}{*}{ Depression } & \multirow{2}{*}{$\begin{array}{l}\text { Job (dis-) } \\
\text { satisfaction }\end{array}$} & \multicolumn{2}{|c|}{ Sickness absence } \\
\hline & & & & Duration & Frequency \\
\hline \multicolumn{6}{|c|}{ Hypotheses involving health outcomes } \\
\hline & Stable high-strain job reports highest level of strain & + & + & + & + \\
\hline & Stable low-strain job reports lowest level of strain & + & $+/-$ & - & - \\
\hline & Stable active job reports average level of strain & + & + & - & - \\
\hline & Stable passive job reports average level of strain & + & + & + & + \\
\hline & Stable high-strain job reports significant increase in strain across time & + & + & - & - \\
\hline $2 b$ & Stable low-strain job reports no significant increase across time & + & + & - & - \\
\hline $3 b$ & Stable active job reports no significant increase across time & + & + & - & - \\
\hline $4 b$ & Stable passive job reports no significant increase across time & + & + & - & - \\
\hline 5 & Change from high-strain job to no-high-strain job results in significant decrease in strain & - & $+/-$ & - & - \\
\hline 6 & Change from no-high-strain job to high-strain job results in significant increase in strain & $+/-$ & $+/-$ & - & - \\
\hline 7 & Change from active or passive work to low-strain job results in significant decrease in strain & + & - & - & - \\
\hline 8 & Change from low-strain to active or passive work results in significant increase in strain & + & - & - & - \\
\hline \multicolumn{6}{|c|}{ Hypotheses involving amount and type of job change } \\
\hline 9 & $\begin{array}{l}\text { Groups reporting major changes in work characteristics (ie, changes from low strain } \\
\text { to high strain or vice versa) report more job changes than other groups }\end{array}$ & \multicolumn{4}{|c|}{+} \\
\hline
\end{tabular}


this change as distressing, when compared with workers with positive demand-control histories. These findings provide converging evidence for the assumption that changes in subjectively experienced well-being can at least partly be traced back to corresponding changes in the work environment.

\section{Study limitations and directions for future research}

One limitation of our study was that, in spite of its fourphase longitudinal design, no causal relationships could be demonstrated in the strictest sense of the word. It is certainly suggestive to see that "objective" and self-reported changes in work characteristics are associated with corresponding changes in worker health, but only well-controlled experimental designs with random assignments of participants to experimental and control groups can provide conclusive evidence in this respect. On the other hand, however, it would seem difficult to conceive a study on the effects of long-term exposure to various combinations of demands and control in a laboratory setting.

A possibly more important limitation of our study concerns the choice of dependent variables. These were taken from a more varied set of outcome variables that may be linked in different degrees to the job characteristics included in the study. One indication that not all the dependent variables were linked to the job characteristics studied in a similar fashion was suggested by the finding that our hypotheses received considerably more support for the subjective outcome variables (ie, depression and job satisfaction) than for the registered sickness absence data (table 7). One explanation for this finding is that sickness absence is a complex measure that may be dependent on factors other than the job characteristics measured. Sickness absence is a multicausal construct influenced, for example, by age, gender, type of job, and behavioral lifestyle variables such as smoking and alcohol intake (33). If this reasoning is correct, the effects of work characteristics on sickness absence are relatively small. Another interpretation of the lack of effects for sickness absence is that job characteristics have an indirect effect on sickness absence that could not be detected in this analysis. The effects of demands and control may affect health indirectly, through psychological outcomes; if so, a longer time may be needed to observe these indirect effects (23).

A related issue is that not all outcome variables included in our study may be considered to represent Karasek's strain concept (1) equally well. In Karasek's conceptualization, strain refers to a chronic affective response to a stressful work environment. In this respect, depressive complaints would seem to be the best representative of strain; job satisfaction would also seem to include motivational aspects and cannot be considered a strain indicator per se. Furthermore, as stated earlier, sickness absence may best be considered the result of a wide range of factors that may or may not be related to the work environment. Thus sickness absence presumably reflects the consequences of prolonged work-related stress to a very limited degree. Consequently, the results found for depression should be deemed more important in reference to the strain hypothesis than job satisfaction or sickness absence is. If this assumption is correct, it is certainly suggestive to see that our hypotheses received the most support for depression, which represents Karasek's strain concept best.

In agreement with these reservations, it would seem important that future longitudinal research explore more and more varied outcomes in relation to the hypotheses presented by us in this study. Can our reported effects be generalized to other populations and outcome variables? Furthermore, these studies should provide a more in-depth exploration of the possible causal links between work and health, examining not only the possible causal effects of work characteristics on worker health, but also possible reverse effects [ie, does worker health influence (perceptions of) the work environment $(12,34)]$. In addition, the effects of work on "objective" health outcomes seem to differ from those on subjectively measured health outcomes. Future research should explore the effects on such "objective" measures in more detail, taking into account the effects of nonwork-related factors.

\section{Practical and theoretical implications}

Despite the limitations and issues for future research that have already been outlined, we believe that our study provides important new insights into the effects of work characteristics on worker health. It extends and enhances the understanding of this relationship in at least three respects. First, this study has demonstrated that Karasek's strain hypothesis (1) should be refined to account for the effects of having an active or passive job, in addition to the standard distinction between low and high strain. Our results provided evidence that the health consequences of having an active or passive job are somewhere in between those of having a high-strain versus low-strain job. Second, the study has demonstrated a clear relationship between subjectively measured changes in health, subjectively reported changes in job demands and control, and "objective" changes in the work environment. Although this relationship lies at the heart of virtually every study employing Karasek's demandcontrol model (1), we believe ours is the first that has empirically tested the links between these concepts. Third, our study has confirmed and further generalized the results presented by Schnall et al (19). Their study was the first to present evidence on the effects of 
cumulative exposure to various combinations of demands and control. Our study extended these results by examining other outcome variables in the context of a larger-scale longitudinal study, showing that the effects of job demands and job control vary as a function of the type of outcome variable - more specifically, of the degree to which an outcome variable corresponds with Karasek's notion of strain (1).

On the basis of the results presented in our study, several theoretical and practical implications emerge. From a theoretical point of view, it is intriguing to see that different types of demand-control histories seem to be differentially associated with various types of health outcomes. These associations can largely be interpreted on the basis of predictions generated by Karasek's demand-control model (1). While previous research has suggested that cumulative exposure to high strain tends to result in negative health outcomes (13-19), our study is the first to explore the effects of exposure to other combinations of job demands and control. Consequently, from a theoretical point of view, it seems worthwhile to explore the differential effects of various demandcontrol histories on worker health.

Another implication originates from the link between the psychosocial self-report measures and the "objective" work environment that was demonstrated in our study. Our results suggest that working in a high-strain job over a prolonged period of time can have detrimental effects on worker health. Job redesign should therefore especially be focused on those who hold a highstrain job or on those who transfer to a high-strain job. Workers who transfer to a high-strain job or who work in a high-strain job may need extra attention to improve their health (34). Counseling should be aimed at preventing the possible negative effects of the current job and helping workers with making the decisions needed to improve their job satisfaction and health. It should be noted that post-hoc analyses revealed that the detrimental effects of working in a stable high-strain job do not vary with age or years of experience. Thus it is not the case that "seniors" profit from their surplus of work experience in dealing with the effects of high strain.

Finally, it is noteworthy that our results showed that a change from a high-strain job to a less distressing job did not, in the short term, result in corresponding improvement in worker health. Thus the effect of having been in a high-strain job seems to have a lasting effect on worker health, even if the work environment changes positively. One explanation for this finding is that the prolonged exposure to high levels of stress and strain has damaged the workers' capacity to recover from jobrelated fatigue (35-37).

The most important conclusion that can be drawn on the basis of our study is that the past seems to matter in determining current health. Cumulative exposure to high job strain has more profound effects on worker health than short-term exposure; the health consequences of having a high-strain job are such that these effects do not disappear swiftly after a change to a low-strain job. Such effects cannot be detected using standard modes of analysis (eg, longitudinal designs in which "time 2" health scores are related to "time 1" health scores and "time 1" job characteristics). In this sense, our study has shed new light on the long-standing issue of the health effects of job demands and control by offering a new paradigm for examining the effects of job characteristics. We believe that our approach can be of considerable value in future research.

\section{Acknowledgments}

This study was financially supported by the Dutch Ministry of Social Affairs and Employment; The Dutch Ministry of Public Health, Welfare, and Sports; and the Dutch National Institute for Social Security.

\section{References}

1. Karasek RA. Job demands, job decision latitude, and mental strain: Implications for job redesign. Adm Sci Q 1979;24: 285-308

2. Schreurs PJG, Taris TW, Schaufeli WB. Arbeidsbelasting, stress en burnout in de zorg [Work load, stress, and burnout in health organizations]. In: Pool J, Van Dijk H, editors. Bouwstenen voor personeelsmanagement in de zorg. Deel 2: Ontwikkeling en duurzame interne inzetbaarheid van personeel [The building bricks for human resource management in health care, part 2: development and interanl employability of personnel]. Houten: Bohn, Stafleu en Van Loghum, 1999: 113-27.

3. Theorell T. Job characteristics in a theoretical and practical health context. In: Cooper CL, editor. Theories of organizational stress. Oxford: Oxford University Press, 2000:205-45.

4. Karasek R, Theorell T. Healthy Work: stress, productivity, and the reconstruction of working life. New York (NY): Basic books, 1990.

5. De Jonge J, Kompier MAJ. A critical examination of the demand-control-support model from a work psychological perspective. Int J Stress Manage 1997;4:235-58.

6. Kristensen TS. Challenges for research and prevention in relation to work and cardiovascular diseases. Scand J Work Environ Health 1999;25:550-7.

7. Van der Doef MP, Maes S. The job demand-control(-support) model and psychological well-being: a review of 20 years of empirical research. Work Stress 1999;13:87-114.

8. De Lange A, Kompier MAJ, De Jonge J, Taris TW, Houtman ILD. Hoogwaardig longitudinaal vragenlijstonderzoek en het Demand-control-(support) model [High quality longitudinal survey research and the demand-control-(support) model]. Gedrag Organisatie 2001;14:254-272. 
9. Johnson JV, Stewart WF. Measuring work organization exposure over the life course with a job-exposure matrix. Scand J Work Environ Health 1993;19:21-28.

10. Landsbergis P, Theorell T. Measurement of psychosocial workplace exposure variables. Philadelphia (PA): Hanley \& Belfus Inc, 2000;15:163-188. Occupational medicine: state of the art reviews, vol 171.

11. Schnall PL, Landsbergis PA, Baker D. Job strain and cardiovascular disease. Annu Rev Public Health 1994;15:381-411.

12. Frese M, Zapf D. Methodological issues in the study of work stress: objective vs subjective measurement of work stress and the question of longitudinal studies. In: Cooper CL, Payne R, editors. Causes, coping and consequences of stress at work. Chichester (United Kingdom): John Wiley \& Sons Ltd, 1988:375-411.

13. Fenwick R, Tausig M. The macroeconomic context of job stress. J Health Soc Behav 1994;35:266-82.

14. Bourbonnais R, Comeau M, Vezina M. Job strain and evolution of mental health among nurses. J Occup Health Psychol 1999;4:95-107.

15. Furda J, de Jonge J, le Blanc P, Meijman T, Schreurs P, Scheenen J. Het Demand-control-support model in relatie tot gezondheidsklachten en herstelklachten: Een longitudinale studie [The demand-control-support model in relation to health complaints and recovery complaints: a longitudinal study]. Gedrag Organisatie 1994;7:225-38.

16. Janssen N, Nijhuis FJN. Herstel van langdurige vermoeidheid bij werknemers: De invloed van positieve veranderingen in werkkenmerken ]Recovery from long-term fatigue in a working population: the influence of positive changes in work characteristics]. Gedrag Organisatie 2001;14:273-90.

17. De Jonge J, Le Blanc PM, Schaufeli WB, Van der Linden S. Verandering in werkkenmerken in relatie tot verandering in burnout en arbeidstevredenheid [Change in job characteristics as related to changes in burnout and job satisfaction]. Gedrag Organisatie 1998;11:121-34.

18. Theorell T, Karasek RA, Eneroth P. Job strain variations in relation to plasma testosterone fluctuations in working men-a longitudinal study. J Intern Med 1990;227:31-6.

19. Schnall PL, Schwartz JE, Landsbergis PA, Warren K, Pickering TG. A longitudinal study of job strain and ambulatory blood pressure: results from a three year follow-up. Psychosom Med 1998;60:697-706.

20. Le Blanc P, De Jonge J, Schaufeli W. Job stress and Health. In: Chmiel N, editor. Work and organizational psychology: a European perspective. Oxford (England): Blackwell Publishers Ltd, 2000:152-5.

21. Selye H. The stress of life. New York (NY): McGraw-Hill, 1976.

22. Kasl SV. Measuring job stressors and studying the health impact of the work environment: an epidemiologic commentary. J Occup Health Psychol 1998;3:390-401.

23. De Jonge J, Reuvers MEN, Houtman ILD, Bongers PM, Kompier MAJ. Linear and nonlinear relations between psy- chosocial job characteristics, subjective outcomes and sickness absence: baseline results from SMASH. J Occup Health Psychol 2000;5:256-68.

24. Ariëns GAM, Bongers PM, Miedema MC, Van der Wal G, Bouter LM, Van Mechelen W. Are neck flexion, neck rotation, and sitting at work risk factors for neck pain? results of a prospective cohort study in occupational setting. J Occup Environ Med 2001;58:200-7.

25. Hoogendoorn WE, Bongers PM, De Vet HCW, Douwes M, Koes BW, Miedema MC, et al. Flexion and rotation of the trunk and lifting at work are risk factors for low back pain: results of a prospective cohort study. Spine 2000;25:308792.

26. Taris TW. A primer in longitudinal data analysis. London: Sage, 2000.

27. Karasek RA. Job content instrument: questionnaire and user's guide. Los Angeles (CA): Department of Industrial and Systems Engineering, University of Southern California, 1985.

28 Radloff LS. The CES-D scale: a self-report depression scale for research in the general population. Appl Psychol Meas 1977;1:485-01.

29. Kohout FJ, Berkman LF, Evans DA, Cornoni-Huntley J. Two shorter forms of the CES-D depression symptoms index. J Aging Health 1993;5, 2:197-3.

30. Wanous JP, Reichers AE, Hudy MJ. Overall job satisfaction: how good are single-item measures? J Applied Psychol 1997;82:247-52.

31. Fienberg SE. The analysis of cross-classified categorical data. 2nd ed. Cambridge (MA): MIT Press, 1980.

32. Knoke D, Burke PJ. Log-linear models. Beverly Hills (CA): Sage, 1980.

33. Allegro JT, Veerman TJ. Sickness absence. In: Drenth PH, Thierry HK, De Wolff ChJ, editors. Handbook of work and organizational psychology. 2nd ed. East Sussex (England): Psychology Press, 1998:121-44.

34. Taris TW, Bok IA, Caljé DG. On the relation between job characteristics and depression: a longitudinal study. Int J Stress Manage 1998;5:157-67.

35. Kompier MAJ. Arbeid en gezondheid van stadsbuschauffeurs [Work and health of city bus drivers] [dissertation]. Groningen (The Netherlands): Rijksuniversiteit Groningen, 1988.

36. Meijman TF, Mulder G. Psychological aspects of workload. In: Drenth PH, Thierry HK, De Wolff ChJ, editors. Handbook of work and organizational psychology. 2nd ed. East Sussex (England): Psychology Press, 1998:5-33.

37. Sluijter JK, Frings-Dresen, MHW, Van der Beek AJ, Meijman TF. The relation between work-induced neuroendocrine reactivity and recovery, subjective need for recovery, and health status. J Psychosom Res 2001;50:29-37.

Reveived for publication: 15 February 2002 